\title{
Expressing a Sense of Readiness
}

about Research Inquiry

In-service Teachers After a Master's Course

DOI: 10.47050/66515321.212-237

Maria Antonietta Impedovo

This paper discusses teachers' sense of "readiness" and what learners know, can do and value between learning and the work setting after attending an international Master's course. To explore this process in an international setting, individual interviews and focus groups were set up with students from two programmes of an international Master's course and narrative data collected at the end of each programme and one year later. The participants were 16 in-service teachers -12 men and 4 women - with an average age of 39, who came to Europe from four African countries (Zimbabwe, Lesotho, Burkina Faso, and Namibia) and Vanuatu (South Pacific islands). The collected data were qualitatively analysed with a category system from three readiness perspectives: conceptual, procedural and dispositional readiness. Exploring the sense of readiness contributes to the field of teachers' professional development and agency-promoting leadership.

\section{Keywords:}

research inquiry

attitude

readiness

internationalisation

teacher training 


\section{Introduction}

Globalisation has increased the internationalisation of education. International teaching courses are characterised by cultural plurality and they have great potential for a teacher's professional learning (Oolbekkink-Marchand, Hadar, Smith, Helleve \& Ulvik, 2017; Lai, Li \& Gong, 2016). A transcultural professional development programme for teachers could stimulate and support the teacher's professional growth (Hoare, 2013), promote transformational learning and make explicit cultural discursive practices (Smith, 2009). However, these international programmes can also be fraught with a predominant one-way perspective and limited knowledge about local resources, opportunities and constraints (Montgomery, 2014). Maximising the benefit of an international teacher's professional learning, it does not depend exclusively on the quality of the training but also on the active engagement of the participants (Edwards, 2015; Priestley, Biesta \& Robinson, 2012) and their capacity to reconcile knowledge between learning and working. This process of the reconstruction and reconciliation of the learning and working settings can be particularly difficult in the international context, especially for under-privileged teaching staff (Djerasimovic, 2014). To explore this active process of the mediation of knowledge in international settings, we have adopted the concept of "readiness", which is interpreted by Billet (2015) as what learners know, can do and value in learning and working. In particular, we focus on the sense of readiness about a specific domain of knowledge that is developed in an international training programme, which has to be adopted in a work setting characterised by social and cultural diversity.

In the first two sections, we will briefly review the theoretical framework related to the research inquiry attitude in professional learning, with a focus on the concept of readiness (Billett, 2015; Billett, Wärvik \& Choy, 2018). Next, we will describe the main study of 16 African in-service teachers who came to Europe to attend an international Master's course, which is oriented to develop a research inquiry attitude. We consider that exploring the teacher's readiness can contribute to understanding more deeply the processes of becoming an agentic teacher, and we aim to find ways to support this development (Kumpulainen \& Lipponen, 2012). 


\section{Expanding Teachers' Professional Learning with a Research Inquiry Attitude}

The current international change in education calls for new competencies and dispositions from teachers, as recognised by the national and international policy and research literature (Bates, Swennen \& Jones, 2011). Teachers' competences are moving beyond boundaries and meaning-making, and they have significant implications in participating in the changes to society and school systems (Renshaw, 2016).

Professional learning is even more critical to schools' sustainable improvement in developing countries. In recent years, many of these countries have seen a resurgent emphasis in educational policy on teacher professionalism and autonomy in place of highly prescriptive curricula and strict regimes of inspection and control (Sahlberg, 2012). For example, the UNESCO programme called 'Education for All' (EFA) faces the challenges of providing quality training to all teachers within a poorly resourced education system. However, Hardman, Ackers, Abrishamian and O'Sullivan express concerns about "the dangers of international agencies urging developing countries to adopt 'best practices' concerning teacher professional development that ignore the everyday realities of the classroom, and the motivations and capabilities of the teachers to deliver such reforms" (2011, p. 670).

Considering teachers as agents of change (e.g. in curriculum-making, see Oliveira, 2012; Priestley, Edwards, Miller \& Priestley, 2012), the individual teachers' capacities for learning new knowledge are significant sources for professional learning. Following this idea, the perspective of teachers as researchers is an interesting point of view that supports the trend that enacts school reform by sustaining teachers' leadership and autonomy in their works (Girod \& Pardales, 2001). This perspective considers the dual demands of being both a reflective teacher and also a researcher who contributes to knowledge development (Cochran-Smith, 2005; Dobber, Akkerman, Verloop $\&$ Vermunt, 2012). Adopting a research inquiry attitude mobilises new skills, demands explicit efforts and commitment from teachers, and asks teachers for a new engagement in challenging traditional practices. According to Billet (2015), the learners' readiness shapes their ability to engage productively in activities and interactions, in training and working, and in learning from these experiences. 


\section{Between learning and working: readiness to engage knowledge in action}

Readiness comprises what individuals know, can do and value. Already used in Piagetian (1968) theories of child development, Billett (2015) applies the concept of learner readiness to the healthcare setting. In a sociocultural constructivist account, the learning is mediated by the kinds of activities in which learners engage as afforded by the social world. Consequently, readiness refers to the individual's abilities to engage with and learn effectively from what they experience, shaping the scope of their learning potential. As proposed by Billet (2015), the point is how learners (i.e. students, apprentices, workers) come to make sense of what they are experiencing, construe meaning from it and learn through it. Specifically, the author proposes that there are three broad dimensions of readiness associated with the knowledge required for practising healthcare professions, which are as follows:

1. Conceptual, factual, propositional (what one knows): this readiness is about being able to make these links and associations thanks to the repertoire of experiences to form purposeful associations and linkages. Thanks to this kind of experience, conceptual associations might arise.

2. Procedural readiness (what one can do): this is the capacity to achieve goals, such as in healthcare work when taking blood. In this case, readiness is likely derived from having had sufficient experience in taking blood samples to perform that procedure without recourse to conscious engagement in that task.

3. Dispositional readiness (what one values): this is the level of occupationally-related dispositions required when drawing upon and utilising knowledge effectively when, for instance, interacting with patients.

According to Billet (2015), these dispositions are central to how individuals elect to engage in these activities, and they also mediate the kind of effort that the individuals exercise in their thinking and acting and, therefore, their learning. Hence, engaging in authentic activities that require the deployment of these three forms of knowledge interdependently is important: "How, for what reasons, and by what degree individuals elect to engage in goal-direct activities is central to what they do and learn" (Billet, 2015, p. 4). This readiness is related 
to teacher agency, which concerns the awareness or experience (Hilppö, 2016) that shapes what teachers do, how they think about what they do, and what they think they will be within their profession. Agentic utilisation and crafting of experiences are crucial for successful professional learning and development (Goller \& Billet, 2014).

In this paper, we are interested in exploring the teacher's sense of readiness. By this term, we mean the attitude expressed by the teachers about how they expand knowledge thanks to their repertoire of experiences (what they know), their attitude about their capacities to achieve goals from having had sufficient experience (what they can do), and their attitude about the level of occupationally-related dispositions required to draw upon and utilise this experience.

Taking this interpretation into consideration, we will investigate the sense of readiness about research inquiry developed by African in-service teachers on an international Master's course through their narratives. This paper contributes to the discussion on how the research dimension is integrated into initial and continuing teacher education courses and what approaches and strategies can be used to integrate theory and practice (Flores, 2017). We explore the personal perspectives of the teachers while also considering the need to see what these are, how teachers engage personally with their professional learning, and how new practices are sustained (Impedovo, 2016).

\section{Aim}

This research aims to find out:

$\rightarrow$ Which sense of readiness is expressed by the teachers' accounts about a specific domain of knowledge developed on a formative training programme?

$\rightarrow$ How is the sense of readiness modulated by teachers between the learning and the work settings?

Taking into consideration the theoretical framework presented above, we will investigate the sense of readiness about research inquiry developed by African in-service teachers on an international Master's course. We hypothesise that the in-service teachers' sense of readiness about the research inquiry attitude acquired during their formative training will shape their attempts to implement this attitude in their daily local work. 
To explore how this engagement starts at the end of their Master's course and evolves after it, the design of this study proposed that teachers were interviewed twice: once at the end of the course and a second time a year later. However, these data do not catch the teachers in action but only the attitude expressed by the teachers during the interviews. For this reason, we explore the 'sense' of their readiness and not their readiness in action.

\section{Participants}

The participants were made up of 16 in-service teachers from two programmes of the same Master's course.

The first programme of the Master's (2014/2015) was attended by a class of nine in-service teachers (six men and three women), and the second programme $(2015 / 2016)$ had a class that was composed of seven in-service teachers (six men and one woman). They all agreed to be involved in this research project. They all had a bachelor's degree in Educational Science with different levels of school teaching experience in their respective countries. The average age of the participants was 39 (ranging from 30 to 50). All of them spoke English as a second language (with different levels of fluency), except for one, who mainly spoke French. Fifteen of them came from four African countries (Zimbabwe, Lesotho, Burkina Faso, and Namibia), and the other came from Vanuatu (South Pacific islands). In all these countries, the teacher's position is characterised by a low status and educational reforms of their education systems are needed (Haßler, Hennessy, Cross, Chileshe \& Machiko, 2015). Reforms are also required to sustain teachers' professional development (Jansen, 2001; Samuel \& Stephens, 2000; Smit \& Fritz, 2008; OECD, 2014). They all received an international fellowship to attend a two-year, full-time international Master's in Educational Research in Europe. A summary of the participants' information is given in Table 1. 
Table 1. Participants of the two programmes of the international Master's

\begin{tabular}{l|l|l} 
& \multicolumn{1}{|c}{ FIRST PROGRAMME } & \multicolumn{1}{c}{ SECOND PROGRAMME } \\
\hline Gender & Male = 6; Female = 3 & Male = 6; Female =1 \\
\hline Country & $\begin{array}{l}\text { Zimbabwe }=3 ; \text { Lesotho }=5 ; \\
\text { Burkina Faso }=1\end{array}$ & $\begin{array}{l}\text { Namibia }=3 ; \text { Lesotho }=1 ; \\
\text { Zimbabwe }=2 ; \text { Vanuatu }=1\end{array}$ \\
\hline Previous degree & Educational Science (bachelor level) & Educational Science (bachelor level) \\
\hline Language & English = 8; French =1 & English =7
\end{tabular}

\section{The Master's degree}

The first part of the Master's course was organised at a Belgian university and the second part at a French university, supported by a European fellowship, for an Erasmus Mundus Joint Master's Degree in Educational Research. This Master's course aimed to improve teaching skills in science education research and to develop a positive research attitude. The Master's course includes training on research methodologies in science education, with a focus on new technology education in teaching. Specifically, the main subjects of the course were: methodology of research, statistics, innovative educational approaches in science education, and the use of educational technology in the classroom. The first part of the Master's had a focus on educational technology, and the second part focused on the quantitative and qualitative methodology of research. To obtain the official qualification, the teachers had to present a final research dissertation that was based on data collected in their local school.

The author of this paper was a teacher on the French part of this Master's course, which allowed for following the second half of the teachers' professional learning process. In the end, the teachers had to prepare a final dissertation that focused on the introduction of technology in teaching and learning practice. Consequently, they collected data in their local contexts during a period spent at home to finalise their work. They continued to work with their supervisor to complete and support their final work. Considering the international nature of the Master's, this course allowed them to improve their professional teaching career and opened up other opportunities for them to obtain new jobs in their home countries. 


\section{Data Collection}

In this paper, we examine two programmes from the same Master's. In both, the teachers were contacted at the end of the Master's course, when they had just finished their training and were about to return to their respective countries. They were then interviewed a second time one year after the end of the Master's.

In the first programme (2014/2015), each participant was interviewed individually and each interview lasted 30 minutes on average. The semistructured interviews were composed of 31 questions (see Annex 1), which were video-recorded and transcribed. Besides the biographical and professional profile (composed of 12 questions), the interview covered two main topics:

$\rightarrow$ Training courses and ongoing research activities (10 questions), which included the topic chosen for their research thesis, their expectations and difficulties related to the learning course and their research activities.

$\rightarrow$ The participants' future projection of how they would use the research skills that they had learnt during the course (9 questions), which included how the teachers saw themselves after the course, projections of the research skills and knowledge acquired into their school, and their relationship with their local communities.

At the end of the second programme (2015/2016), the data were collected based on the same protocol; that is, through in-depth discussions of the participants' research skills and activities.

In both programmes, the same interview was repeated one year after the completion of the Master's. By this time, the participants had already submitted their final dissertation based on data collected in their local schools, obtained their official qualification and were living in their respective countries. This second interview contained eight questions that focused on the two main topics considered in the first interview: training courses and their use of the research skills learnt (see Annex 2). The interviews were conducted via Skype with subsidiary asynchrony chats conducted when needed.

The data collection methods chosen aimed at stimulating the reflections of the participants to obtain richer data from which 
to extrapolate the teachers' sense of readiness in applying the research inquiry attitude between learning and working in the classroom.

\section{Data Analysis}

An initial overview of all the data (interviews and videos) was carried out by two researchers to familiarise themselves with the corpus of data. During this phase, the extracts considered as capable of giving insights about the teachers' sense of readiness were selected and, later, themes connected to expressions of their sense of readiness were identified (Charmaz, 2006; Mayring, 2004; Neuendorf, 2016). This circular process was oriented by the theoretical framework. Specifically, the themes were examined in reference to Billet's three dimensions of the concept of readiness (2015), as viewed from the perspective of knowledge: (1) conceptual, (2) procedural and (3) dispositional. At the same time, three temporal dimensions were also considered:

$\rightarrow$ the sense of readiness before completing the Master's degree,

$\rightarrow$ the sense of readiness right after completing the Master's degree, and

$\rightarrow$ the sense of readiness one year after completing the Master's degree.

The first two dimensions of the teachers' thoughts were collected during the first round of interviews. The last was collected during the second round of interviews. As such, there were three temporal dimensions but only two rounds of interviews.

These were traced directly from the teachers' accounts. Consequently, for each dimension, there are three sub-categories related to the temporal perspectives (see Table 2). 
Table 2. Codebook of the Sense of Readiness

\begin{tabular}{|c|c|c|c|}
\hline DIMENSION & DESCRIPTION & SUB-CATEGORIES & EXAMPLE \\
\hline \multirow{3}{*}{$\begin{array}{l}\text { Sense } \\
\text { of conceptual } \\
\text { readiness }\end{array}$} & \multirow{3}{*}{$\begin{array}{l}\text { expand knowledge } \\
\text { thanks to my repertoire } \\
\text { of experiences } \\
\text { (what I know) }\end{array}$} & $\begin{array}{l}\text { before } \\
\text { the Master's }\end{array}$ & $\begin{array}{l}\text { "I want to use this } \\
\text { technology in my teaching". }\end{array}$ \\
\hline & & right after & $\begin{array}{l}\text { "I am ready and I have } \\
\text { something new in mind". }\end{array}$ \\
\hline & & one year on & $\begin{array}{l}\text { "It opened my eyes towards } \\
\text { the use of technology". }\end{array}$ \\
\hline \multirow{3}{*}{$\begin{array}{l}\text { Sense } \\
\text { of procedural } \\
\text { readiness }\end{array}$} & \multirow{3}{*}{$\begin{array}{l}\text { capacity to achieve } \\
\text { goals from having had } \\
\text { sufficient experience } \\
\text { (what I can do) }\end{array}$} & $\begin{array}{l}\text { before } \\
\text { the Master's }\end{array}$ & $\begin{array}{l}\text { "Previously, I just waited } \\
\text { and I was frustrated". }\end{array}$ \\
\hline & & right after & $\begin{array}{l}\text { "Now we can play } \\
\text { an important role, we will } \\
\text { implement simulations } \\
\text { in our classrooms". }\end{array}$ \\
\hline & & one year on & $\begin{array}{l}\text { "I am helping some } \\
\text { colleagues with how } \\
\text { to do research". }\end{array}$ \\
\hline \multirow{3}{*}{$\begin{array}{l}\text { Sense } \\
\text { of dispositional } \\
\text { readiness }\end{array}$} & \multirow{3}{*}{$\begin{array}{l}\text { level of occupationally- } \\
\text {-related dispositions } \\
\text { required to draw upon } \\
\text { and utilise } \\
\text { experience } \\
\text { (what I value) }\end{array}$} & $\begin{array}{l}\text { before } \\
\text { the Master's }\end{array}$ & $\begin{array}{l}\text { "In my country, there is not } \\
\text { motivation. I do not have it". }\end{array}$ \\
\hline & & right after & $\begin{array}{l}\text { "Research really can help } \\
\text { teachers with teaching } \\
\text { approaches so they can } \\
\text { help the students better". }\end{array}$ \\
\hline & & one year on & $\begin{array}{l}\text { "I would like to engage } \\
\text { myself more in research } \\
\text { projects". }\end{array}$ \\
\hline
\end{tabular}

Considering the exploration of the sense of readiness in the teacher narrative, discursive and linguistic indicators of the agency have been identified (action verb, reference to a personal or collective action).

In line with Billet (2015), we consider these three dimensions separately but as interdependently related, and they are not exclusive categories. The two researchers compared their outcomes and discussed controversial cases (about $30 \%$ ) with a third researcher. Once a total agreement on the data's interpretation had been reached, they selected the most representative cases for each category to be reported and discussed in this paper is a qualitative process (Bryant \& Charmaz, 2007). 
In the next section, the findings of the study are presented. The data of the two programmes are grouped and presented according to the three categories and sub-categories reported above.

\section{Findings}

For each section, we analyse the three categories concerning the three temporal sub-categories considered (i.e. before the Master's, right after the end of the Master's, and one year on from the end of the Master's) with the use of extracts from the teachers' interviews. The first section discusses the participants' accounts of their sense of conceptual readiness.

\section{Sense of Conceptual Readiness}

Before the Master's

In general, the teachers expressed a need for professional development and learning. This personal need was related to the desire to help students improve their performance and to indirectly affect colleagues and, more generally, the community to which they belonged. Therefore, the teachers saw the Master's as a source of knowledge and methods to help them to renew their role as teachers, as in the following extract:

I would like to know how to approach this net-generation with new teaching methods. For that reason, I choose to go on with my studies and return to deal with this challenge. [Extract No. 1]

Teachers are ready to engage in learning and training for their professional development for different reasons. Technology knowledge is particularly considered to improve teaching in modern society, a feeling that all the teachers expressed. This confirms their need for new knowledge and content to deal with changes in modern African society.

Right after the end of the Master's The training course activated new potential practices of teaching and the teachers' involvement in research generated new knowledge. When new knowledge is acquired, this starts to intertwine with implications for their teaching practices. In the following extract (No. 2), the teacher explored the potential link between her future action of doing research, 
possibly thanks to the experience she had acquired, and the impact on her students:

When you are a teacher you use the knowledge that you know and use the results you just had. But as a researcher, you have to read what other people have done, what other people have to teach you, how you can use this and then you can expand. My students will be better now. I will try to stay in research. Oh yes, I am ready and I have something new in mind. [Extract No. 2]

The course enriched her vision of teachers and she projected herself as a researcher with a new modality of practices, such as reading educational and scientific literature and taking part in discourses in the educational community. The knowledge acquired by the teachers is seen to be directly linked with the knowledge and performance of the students. She considered that engaging in research, with a focus on both knowledge acquired and knowledge still to be appropriated, will help to improve her own students' performance.

One year on

One year on from the end of the Master's, the teachers still valued and considered the knowledge they had acquired, which had been adapted and tested in different pedagogical solutions. Teacher values, particularly the global opportunity given by the Master's, had been exposed to a new culture, a new educational system and new content that stimulated their professional growth, as in these two extracts:

Being exposed to ideas, education systems in Europe has helped me to realise not to stick to an education system as a fixed body but to discover new ideas that flow into the classroom for the best results. [Extract No. 3]

To improve my teaching methods and to be open-minded in other areas of life. Research has helped me to keep searching for ways to improve or to possess new skills in my current occupation and any other work-related areas. [Extract No. 4] 
One year on from the end of the Master's, it is the teachers' global experience in Europe, in its totality, that has shaped their new conceptual perspectives about education, pedagogy and national practices. Teachers, apart from the pedagogical implications, evoke their engagement to become more oriented to a social perspective. Their conceptual readiness is oriented towards activating their knowledge to solve general problems in their African community, such as the penury of teaching resources and the poor quality of science laboratory tools. The teacher's role has been re-conceptualised and enriched with a new commitment and important implications (albeit still generic) for the social community.

\section{Sense of Procedural Readiness}

Before the Master's

The teachers recognised they could not act as active teachers in their work because they were demotivated for different reasons, such as the poor resources available and the absence of support. In Extract No. 5 , the teacher is clearly stating that she was waiting for something - it is not clear what - that did not arrive, which made her frustrated. Indeed, frustration and a lack of motivation were the basis of passive action that made it impossible for the teachers to change their teaching strategies.

\section{Previously, I just waited and I was frustrated. [Extract No. 5]}

Their willingness to act under new practices was inhibited by the absence of new stimuli, which would subsequently be filled by the Master's course.

Right after the end of the Master's

The teachers felt that they could do research thanks to the new tools they had acquired. They were ready to act in new ways and with an activated sense of procedural readiness for research inquiry, as the following extract testifies:

If I come back home now, I will teach, I think, I will see research differently. If you see a problem in your classroom, maybe the students are not learning, so you have to ask yourself, why are 
the students not learning? If you decide to do such a research you will be able to find an answer. So, for this reason, research can be done. It can help. [Extract No. 6]

The teacher in this extract feels ready to apply their acquired knowledge in the new context, imagining scenarios of intervention. This knowledge is active in terms of organising new pedagogical activity and doing research, which expresses their sense of readiness in applying a research inquiry attitude.

The teachers were also aware that peer collaboration has the potential to transform teaching practices. They often referred to the concrete planning to share their expertise with other colleagues involved in the research. For example:

When I go back to my school, I will organise a series of workshops for my colleagues, as well as in the neighbouring school. [Extract No. 7]

This sort of collective action is considered valuable in supporting changes in teaching practices. In general, teachers had begun to evaluate the benefits of the acquisition of research skills, which extended their traditional action space. Indeed, some generic implications of their doing research in the school - for the benefit not just of the classroom but also of society - began to emerge:

I will do research and be able to resolve more problems.

[Extract No. 8]

However, this procedural readiness is, at the same time, generic and over-optimistic about the implication of teachers' research on the local community.

One year on

The teachers still claim to apply and consider the knowledge they acquired about research inquiry and that this has led to some stable and significant changes in their practices. Indeed, some practices are well assimilated in their daily activities, as shown in this extract: 
I have identified what type of students I have in class, detected the learning style that suits their learning needs. [...] Since I have activated the students' curiosity in the classroom, learning is effective, and I can tell that students have gained a lot from the different types of teaching methods I have prepared for each lesson. [Extract No. 9]

Here, the teacher is attempting to build a network with his colleagues in his local context. There is an active effort to create a shared repertoire with colleagues for the common goal of improving the performances of the students.

The teachers' actions also include going on with their research, for example:

I am currently working on the publication of my research paper.

[Extract No. 10]

As shown in this extract, great emphasis is placed not only on what can be taken from the research but also on the potential to contribute to research. Consequently, one year after the end of their Master's course, the teachers are still dealing with research, which can open new possibilities for their career and the quality of their teaching.

\section{Sense of Dispositional Readiness}

Before the Master's

The teachers expressed a sense of frustration in their dispositional readiness, considered as the level of occupationally-related dispositions available for them to draw upon and with which they could utilise their knowledge effectively (i.e. what they value). They characterised the existing activity as a failure, and many had lost their motivation to continue to work. In the following extract, a teacher refers to the sense of frustration they experienced:

I do not know, maybe in another country it is different, but in my country, the conditions are very bad, the instruments that we give to kids are very poor: so, it is not efficient to be a teacher. In my country, there is not motivation. I do not have it. [Extract No. 11] 
In this extract, the teacher realises the absence of personal engagement as a consequence of economic depression and passivity from the country-level educational institutions.

Right after the end of the Master's

At this stage, the teachers' sense of dispositional readiness in applying research inquiry is active, with high expectations and a positive bias about educational research, as in the following example:

I mean to find a way to teach in a limited situation. Only true research can improve the situation. [Extract No. 12]

As we can see, taking part in the course has given a powerful boost to breaking away from previous practices and finding new solutions to overcome obstacles. Teaching is seen as a space in which to apply and experience new strategies, while research is seen as a space to find new resources, solutions, and problem-solving insights. However, despite this positive disposition, some of the teachers were also aware of the obstacles and slowness of social transformation, as seen in this extract:

Another concern is the situation of the internet. We have already downloaded the simulation programmes, but we are still worried because so far we cannot access the internet freely. [...] I am aware that this will be a challenge at home. [Extract No. 13]

The problems with the lack of technology were a shared concern for the teachers who would have liked to introduce some innovations into their teaching practices. Their continued belonging and access to the research communities were seen as crucial for enacting these changes.

One year on

The teachers affirmed that becoming a teacher is generally easy in their respective countries of origin. However, teaching is described as a low paid profession with limited social status and with few opportunities for professional learning. One year after the end of the Master's, 
the experience was still central to their professional development, as seen in this extract:

The Master's of Research was a journey that changed my profession.

[Extract No. 14]

Apart from recognising the value of the Master's in its entirety, this teacher expresses that their future disposition was strongly oriented towards research. However, while the Master's course had helped them to take new actions to improve their skills and take opportunities, one year later, the teachers seem to be struggling individually for professional growth. For example:

I would very much love to continue research in education.

Educational science in my country still needs a lot of research

to improve the education system. If I am given a chance,

I would like to continue doing research. [Extract No. 15]

Positive in their research-oriented dispositions in the final interview one year after finishing their Master's course, teachers are looking for new opportunities to pursue a path of professional growth.

\section{Discussion}

The purpose of this paper was to look into teachers' sense of readiness about a specialist domain, which is the research inquiry attitude. In the following, we discuss the narrative data obtained at the end of the Master's and one year on in the light of the three categories considered.

The category "sense of conceptual readiness" shows the ability of the teachers to make new conceptual links about teaching practices thanks to the repertoire of experiences acquired during their Master's course. Beforehand, the teachers felt the need for new knowledge to adapt their job to the demands of the students and society. This absence leads to the difficulty of keeping up with their habitual way of working while also considering the lack of motivation, resources and new strategies to deal with young students. These teachers had started to search for new actions and opportunities, 
such as the learning opportunities of the Master's course. One year on, the teachers expressed the importance of the Master's as a moment in which they felt 'charged' with the new knowledge desired.

The category 'sense of procedural readiness' is characterised by an inhibition of action before the course. At the end of the Master's and one year on, the teachers had introduced some changes into their role as teachers, revising their working practices with more use of technology in the classroom, although always while dealing with limited resources. At the same time, the teachers were willing to engage in shared reflections about potential social transformation thanks to their actions.

The category "sense of dispositional readiness" is characterised at the end of the Master's with a renewed personal commitment towards the profession. By the end of the course, the teachers were willing to stay in research activities (such as publishing papers). This engagement is considered as a personal and professional advantage but, for some of them, also has the social implication of contributing their countries.

The three categories and sub-categories help us to see in detail the journey from learning to work made by the teachers in their process of professional development until one year after the end of their Master's. This process and its related experiences help us to see how the knowledge is "digested" over time with different levels of attention from their side (attention to specialist knowledge at the beginning of the course and more global at the end, with a wider appreciation of the Master's) in sedimentation of the learning done.

The peculiar cultural and economic situations in the countries the teachers came from seeming to shape the elaboration of their knowledge in evaluating the teaching profession and the possible projection of actions to perform at a personal and social level. Indeed, the teachers mentioned their adaptation between the learning done and the features of their contexts, shaping their ability to implement innovative teaching practices, and, concerning their procedural and dispositional readiness, discussed sharing in colleagues' experiences, proposing new solutions in the classroom and so on. The research inquiry attitude thus shaped new possibilities of pedagogical and professional action for these teachers.

Considering the international context between Africa and Europe, we feel that this study may open a discussion about how to transfer the conceptual, disposition and procedural readiness acquired 
in an international training arena to local practices, where challenges could be found in daily working life, such as for our sample of teachers. The study of readiness and senses of readiness in teaching practices helps us to deeply explore the transition between learning and practice and the agentic role of the teacher in these revisions of knowledge.

Indeed, supporting the ability to introduce and use new knowledge, practices and innovations in a specific context is what it means to be an agentive teacher. Agency, which is here conceptualised as an individual or collective willing to act, is an integral part of a teacher's professionalism and involves the capability to conceive broad educational visions and meanings that give a long-term purpose to the work (Toom, Pyhältö \& Rust, 2015). Specifically, the teachers' agency is here conceptualised as the opportunity, will and skill to act upon, influence and transform activities and circumstances in their professional lives (Emirbayer \& Mische, 1998). Specifically, the teachers' sense of agency concerns the awareness or experience (Hilppö, 2016) that shapes what teachers do, how they think about what they do, and what they think they will be within their profession. Considering teachers' agency related to their capacity to act combined with the contingencies of the environment within which such action occurs (Biesta \& Tedder, 2007) and their senses of conceptual, procedural and dispositional readiness thus help us to decode what the teachers know, do and value.

\section{Conclusions}

In this chapter, we have explored a group of teachers' senses of readiness about their research inquiry attitudes after attending an international Master's course. From a methodological point of view, in exploring the sense of readiness of in-service teachers, this paper is limited because it considered a small number of respondents. Nevertheless, the case study considered allowed patterns to emerge (Zittoun, 2016). Indeed, self-narratives are a powerful instrument to explore the subjective point of view about professional learning and development, as well as changes related to the acquisition of a research inquiry attitude. At the same time, we are aware of the complexity of the concept and the difficulties in the operationalisation of the sense of readiness. Further research is needed in this direction, considering the small amount of current literature about the concept of readiness 
and senses of readiness; for example, research may aim to see readiness in direct action or constraints in the introduction of innovations into local communities, considering that instructional practices are generally highly institutionalised (Bridwell-Mitchell, 2015). More broadly, the paper contributes to the field of teachers' professional development and agency-promoting leadership (Vähäsantanen, Paloniemi, Hökkä \& Eteläpelto, 2017). Teachers may become aware of their agency thanks to their professional learning, how it affects their professional experiences, and how it may affect students' learning. Meanwhile, future research may shed light on how to support agency in a changing context (Rajala \& Kumpulainen, 2017) and how to actively use learning to have a real impact in the work setting.

\section{References}

$\rightarrow$ Bates, T., Swennen, A. and Jones, K. (2011). Teacher educators - a professional development perspective, The Professional Development of Teacher Educators, 1, 7-19.

$\rightarrow$ Billett, S. (2015). Readiness and learning in healthcare education, Clinical Teacher, 12, 1-6.

$\rightarrow$ Billett, S., Wärvik, G. B. and Choy, S. (2018). Concepts, Purposes and Practices of Integration Across National Curriculum. In: S. Choy, G.-B. Wärvik, V. Lindberg (eds.), Integration of Vocational Education and Training Experiences (pp. 327344). Singapore: Springer.

$\rightarrow$ Bridwell-Mitchell, E. N. (2015). Theorizing teacher agency and reform: How institutionalized instructional practices change and persist, Sociology of Education, 88(2), 140-159.

$\rightarrow$ Bryant, A. and Charmaz, K. (2007). Grounded Theory Research: Methods and Practices. In: A. Bryant, K. Charmaz (eds.), The Sage Handbook of Grounded Theory (pp. 31-57). Los Angeles: Sage Publications.

$\rightarrow$ Charmaz, K. (2006). Constructing grounded theory: A practical guide through qualitative analysis. London: Sage Publications.

$\rightarrow$ Cochran-Smith, M. (2005). Teacher educators as researchers: Multiple perspectives, Teaching Teachers, 21(2), 219-225.

$\rightarrow$ Djerasimovic, S. (2014). Examining the discourse of cross-cultural communication in transnational higher education: from imposition to transformation, Journal of Education for Teaching, 40(3), 204-216. 
$\rightarrow$ Dobber, M., Akkerman, S. F., Verloop, N. and Vermunt, J. D. (2012). Student teachers' collaborative research: Small-scale research projects during teacher education, Teaching and Teacher Education, 28(4), 609-617.

$\rightarrow$ Edwards, A. (2015). Recognising and realising teachers' professional agency, Teachers and Teaching: theory and practice, 21(6), 779-784.

$\rightarrow$ Emirbayer, M. and Mische, A. (1998). What Is Agency?, The American Journal of Sociology, 103(4), 962-1023.

$\rightarrow$ Flores, M. F. (2017). Practice, theory and research in initial teacher education: international perspectives, European Journal of Teacher Education, 40(3), 287-290.

$\rightarrow$ Girod, M. and Pardales, M. (2001). "Who am I Becoming?" Identity Development in Becoming a Teacher Researcher. Paper presented at the Annual Meeting of the American Educational Research Association, Seattle, WA, 10-14 April.

$\rightarrow$ Goller, M. and Billett, S. (2014). Agentic behaviour at work: Crafting learning experiences. In: M. Goller, S. Paloniemi, Discourses on professional learning (pp. 25-44). Dordrecht: Springer.

$\rightarrow$ Haßler, B., Hennessy, S., Cross, A., Chileshe, E. and Machiko B. (2015). School-based professional development in a developing context: lessons learnt from a case study in Zambia, Professional Development in Education, 41(5), 806-825.

$\rightarrow$ Hardman, F., Ackers, J., Abrishamian, N. and O'Sullivan, M. (2011). Developing a systemic approach to teacher education in sub-Saharan Africa: Emerging lessons from Kenya, Tanzania and Uganda, Compare: A Journal of Comparative and International Education, 41(5), 669-683.

$\rightarrow$ Hilppö, J. (2016). Children's sense of agency: A co-participatory investigation. Doctoral thesis. University of Helsinki, Helsinki.

$\rightarrow$ Hoare, L. (2013), Swimming in the deep end: transnational teaching as culture learning?, Higher Education Research \& Development, 32(4), 561-574.

$\rightarrow$ Impedovo, M.A. (2016). In-service Teachers' Sense of Agency after Participation in a Research Master Course, International Journal of Educational Psychology, 5(3), 281-307.

$\rightarrow$ Jansen, J.D. (2001). Image-inning teachers: Policy images and teacher identity in South African classrooms, South African Journal of Education, 21(4), 242-246.

$\rightarrow$ Kumpulainen, K. and Lipponen, L. (2012). Harnessing funds of knowledge in dialogic inquiry across formal and informal learning environments. In: P. Jarvis, M. Watt (eds.), The Routledge international handbook of learning (pp. 112-125). New York: Routledge. 
$\rightarrow$ Lai, C., Li, Z. and Gong, Y. (2016). Teacher agency and professional learning in cross-cultural teaching contexts: Accounts of Chinese teachers from international schools in Hong Kong, Teaching and Teacher Education, 54, $12-21$.

$\rightarrow$ Neuendorf, K. A. (2016). The content analysis guidebook. London: Sage Publications.

$\rightarrow$ Mayring, P. (2004). Qualitative content analysis, A companion to qualitative research, 1, 159-176.

$\rightarrow$ Montgomery, C. (2014). Transnational and transcultural positionality in globalised higher education, Journal of Education for Teaching, 40(3), 198-203.

$\rightarrow$ OECD (2014). Reviews of Vocational Education and Training A Skills beyond School Review of South Africa. Paris: Organisation for Economic Co-operation and Development Publishing.

$\rightarrow$ Oolbekkink-Marchand, H. W., Hadar, L. L., Smith, K., Helleve, I. and Ulvik, M. (2017). Teachers' perceived professional space and their agency, Teaching and Teacher Education, 62, 37-46.

$\rightarrow$ Oliveira, A. W. (2012). Teacher agency in the performance of inquiry-oriented science curriculum reform, Cultural Studies of Science Education, 7, 569-577.

$\rightarrow$ Piaget, J. (1968). Le point de vue de Piaget, International Journal of Psychology, 3(4), 281-299.

$\rightarrow$ Priestley, M., Biesta, G. J. J. and Robinson, S. (2012). Understanding teacher agency: The importance of relationships, Paper presented at the Annual Meeting of the American Educational Research Association, Vancouver, Canada, 13-17 April.

$\rightarrow$ Priestley, M., Edwards, R., Miller, K., Priestley, A. (2012). Teacher agency in curriculum making: Agents of change and spaces for manoeuvre, Curriculum Inquiry, 43(2), 191-214.

$\rightarrow$ Rajala, A. and Kumpulainen K. (2017). Researching Teachers' Agentic Orientations to Educational Change in Finnish Schools. In: M. Goller, S. Paloniemi, Agency at Work. Professional and Practice-based Learning (Vol. 20, pp. 311-329). Cham: Springer.

$\rightarrow$ Renshaw, P. (2016). On the notion of worthwhile agency in reformist pedagogies, Learning, Culture and Social Interaction, 10, 60-63.

$\rightarrow$ Samuel, M. and Stephens, D. (2000). Critical dialogues with self: Developing teacher identities and roles - a case study of South African student teachers, International Journal of Educational Research, 33(5), 475-491.

$\rightarrow$ Sahlberg, P. (2013). The most wanted: Teachers and teacher education in Finland. In: Teacher education around the world (pp. 15-35). New York: Routledge. 
$\rightarrow$ Smith, K. (2009). Transnational teaching experiences: an under-explored territory for transformative professional development, International Journal for Academic Development, 14(2), 111-122.

$\rightarrow$ Smit, B. and Fritz, E. (2008). Understanding teacher identity from a symbolic interactionist perspective: two ethnographic narratives, South African Journal of Education, 28(1), 91-101.

$\rightarrow$ Vähäsantanen, K., Paloniemi, S., Hökkä, P. and Eteläpelto, A. (2017). An agency-promoting learning arena for developing shared work practices. In: M. Goller, S. Paloniemi (eds.), Agency at work: An agentic perspective on professional learning and development (pp. 351-371). Cham: Springer.

$\rightarrow$ Zittoun, T. (2016). Modalities of generalization through single case studies, Integrative Psychological and Behavioral Science, 51(2), 171-194. 


\section{Annex 1}

The first interview that was done at the start of the programme

Autobiographical and professional profile

1. Gender

2. Age

3. Nationality

4. What was your last academic qualification?

5. What is your subject of teaching?

6. How many years of teaching have you done?

7. In which school do you work?

8. Why did you choose to be a teacher? How do you become a teacher?

9. What are the basic elements to be a teacher?

10. Do you think that there were significant turning points in your professional career? Which?

11. When and why did you decide to improve your professional skills?

12. Who supported you in this decision?

Learning course and ongoing research activities

1. Why and how did you choose the topic of your research thesis?

2. What is your main expectation in doing your research?

3. What are the main difficulties in organising your research?

4. Is this the first time that you have done research?

5. What role do your supervisor and colleagues have in your research?

6. Do you consider your previous experience as a teacher when doing your actual research? If yes, how?

7. What kind of new technology do you use for doing your research?

8. Do you use some online social networks or websites to connect with other researchers or teachers?

9. Do you think you have developed skills while doing your research? If yes, can you give some examples?

10. Do you like to do research in education? 
Projection of skills acquired in future activities

1. Do you think your experience during the Master's will be useful in your future teaching activities? In what way?

2. Do you think your experience during the Master's will be useful for your future students? In what way?

3. Will you share your experience of learning and research with other teachers in your school? If yes, in what way?

4. Do you think you will continue to improve your skills? If yes, how?

5. Do you feel confident to start new research in your local school in the future?

6. Will you use new technology to improve your research skills? If yes, which technology?

7. According to you, do teachers need to develop research skills? Why?

8. What is the attitude of your school about research activities?

9. What kind of relationship is there between your school and your local university? 


\section{Annex 2}

Interview Protocol

1. After more than a year since the end of your international Master's course, are you still interested in your research topic?

2. On returning to your country, did you share the results of your research with colleagues/students or other schools? In what way?

3. In your opinion, what is the most important contribution of your research in your school and/or community?

4. Do you think that doing your research has had an impact on your teaching practices? In what way?

5. Have you published, or do you plan to write, articles about your research?

6. Are you involved in new research projects?

7. Do you intend to improve your professional skills? In what way? 